\title{
Management of Grass and Broadleaf Weeds in Processing Potatoes (Solanum tuberosum L.) with Clomazone, in the Argentinian Pampas
}

\author{
Daniel Osmar Caldiz¹, Carolina de Lasa², Pablo Eugenio Bisio² \\ ${ }^{1}$ Global Agronomy R \& D, McCain Foods Limited, San Isidro, Argentina \\ ${ }^{2}$ Field Department, McCain Argentina SA, Balcarce, Argentina \\ Email: dcaldiz@mccain.com.ar
}

How to cite this paper: Caldiz, D.O., de Lasa, C. and Bisio, P.E. (2016) Management of Grass and Broadleaf Weeds in Processing Potatoes (Solanum tuberosum L.) with Clomazone, in the Argentinian Pampas. American Journal of Plant Sciences, 7, 23392348.

http://dx.doi.org/10.4236/ajps.2016.716205

Received: September 2, 2016

Accepted: November 25, 2016

Published: November 28, 2016

Copyright $\odot 2016$ by authors and Scientific Research Publishing Inc. This work is licensed under the Creative Commons Attribution International License (CC BY 4.0).

http://creativecommons.org/licenses/by/4.0/ (c) (i) Open Access

\begin{abstract}
Weed competition in the potato crop could cause up to a $95 \%$ yield reduction depending on the variety, the weed species and the competition period. In this work the effect of Clomazone (Command $36 \mathrm{CS}^{\oplus}$ ), when applied alone or in combination with Metribuzin (Sencorex ${ }^{\oplus} 48$ ) upon grass and broad-leaved weeds was assessed. The work was carried out under the environmental conditions of the Argentinian Pampas, where close to $50 \%$ of the potatoes produced in the country are grown. The field trial was performed during the spring-summer crop, season 2008/09, with cv. Innovator, in a completely randomized design of the following treatments: (a) control, without weed control; (b) Clomazone $1.6 \mathrm{l} \cdot \mathrm{ha}^{-1}$; (c) Clomazone $2.0 \mathrm{l} \cdot \mathrm{ha}^{-1}$; (d) Clomazone $1 \mathrm{l} \cdot \mathrm{ha}^{-1}+$ Metribuzin $0.75 \mathrm{l} \cdot \mathrm{ha}^{-1}$; (e) Clomazone $1.6 \mathrm{l} \cdot \mathrm{ha}^{-1}+$ Metribuzin 0.5 l.ha ${ }^{-1}$; and (f) Metribuzin $1.35 \mathrm{l} \cdot \mathrm{ha}^{-1}$. Treatment effectiveness (TE), crop competition level (CCL) and weed suppression index (WSI) were assessed at 38, 53 and 72 days after planting (DAP), while yield and quality were also evaluated, following industry protocols. In those treatments were Clomazone was used alone, at $2 \mathrm{l} \cdot \mathrm{ha}^{-1}$, or combined (Clomazone $1 \mathrm{l} \cdot \mathrm{ha}^{-1}+$ Metribuzin $0.75 \mathrm{l} \cdot \mathrm{ha}^{-1}$ ), a higher yield was observed. Besides, a high correlation between TE, WSI and tuber yield was also achieved. Clomazone improved TE, CCL and WSI, which was not only reflected in higher tuber yields, but also on better tuber quality.
\end{abstract}

\section{Keywords}

Clomazone, Weed Competition, Potato, Tuber Yield

\section{Introduction}

Potato is one of the most important crops worldwide, occupying the third place as 
staple food after rice and wheat [1]. Therefore, it is a critical crop in terms of food security, taking into account the growth of the world's population. Besides, demand of processed products is also increasing, and according to FAO, more than two thirds of the global annual harvest is destined for human consumption and the rest for industrial purposes [2]. Within Latin America, Argentina is the third producing country, with more than $2.5 \mathrm{M}$ tons produced per year, and almost $50 \%$ of that volume is grown in the Argentinian Pampas, both for the market and the processing industries [3] [4].

Despite several yield increases, due to the introduction of new cultivars, improved in the seed production system and quality, and a high adoption of technology [3] [5] [6], weed management is still critical, due to the poor competition ability of the crop [7], and also due to the limited number of herbicides available to apply on potatoes, in Argentina [8]. Weeds compete for space, water, radiation, and nutrients [7]. In addition, some weeds have an allelopathic effect onto the crop [9] and others can host potato virus [10]. Weed effects depend on population density, competitive ability of each potato variety and the co-existent period with the crop [7] [9] [11] [12]. Main weed effects are due to reductions in yield and quality. Yield reductions caused by the presence of weeds may vary between $19 \%$ - $81 \%$ [13]. These authors found that densities as low as 1 weed plant per linear $\mathrm{m}^{-1}$ is enough to significantly reduce crop yield. Beltrano and Caldiz [9] found similar results, caused by different densities of Johnson grass (Sorghum halepense). The latter authors found that 17,34 and 51 plants $\cdot \mathrm{m}^{-2}$ of Johnsongrass decreased tuber yield by $80 \%, 85 \%$ and $95 \%$, respectively. However, in potatoes, due to the poor competition ability of the crop, when weeds emerged at the same time of the crop up to $54 \%$ yield reduction was observed, compared with a $16 \%$ yield reduction when weeds emerged three weeks after the crop [14] Results obtained during the evaluation of pre-emergent herbicides in cv. Kennebec shown that the presence of annual weeds such as Common Lambsquarter (Chenopodium album) and Purslane (Portulaca olearaceae) can cause yield reductions between $11 \%-29 \%$ when the weedy control was compared with the best treatment [3]. Besides, Hutchinson [12], also determined for the variety North Norkotah -which has a low competitive ability-, a critical period from 10 - 24 days after emergence where the crop should remain free of weeds to only suffer a yield reduction not greater than $5 \%$. Initial weed competition can decrease yield, while competition at the end of crop cycle, such as the one exert by Pigweed (Amaranthus quitensis), Common Lambsquarter, Bermuda Grass (Cynodon dactylon) and Field Binweed (Convolvulus arvensis) could not only reduce yield but could also interfere with harvest operations [3] [7].

As already mentioned, in Argentina, availability of selective herbicides to apply in potatoes are limited, being the post-emergence period the more critical in this regard, mainly when broadleaf weeds are considered [8]. Herbicides registered to use on the potato crop are Fluorochloridon, Linuron, MCPA, Rimsulfuron (Titus ${ }^{\circledR}$, Dupont Company, available since 2015) Trifluralin, and Metribuzin [15], while Flumioxazin is still under the registration process (Caldiz, D.O. personal communication). With this limited number of herbicides available, crop management becomes more difficult as 
none of this could be used to deal with all weed species.

Black thistle (Cirsium vulgare), Spiny Cocklebur (Xanthium spinosum), Turnip (Brassica campestris), Cultivated Radish (Raphanus sativus), Common Lambsquarter, Purslane, Annual Vine (Polyginum convolvulus), Knotweed (Polygonum aviculare), Fierce Thorn Apple (Datura ferox), Marigold (Tagetes minuta), Pigweed, and Sunflower (Helianthus annuus) can be mentioned as weeds that are control by herbicides registered for potatoes, among others. However not all of these species are controlled with the same effectiveness; for example, Trifularin does not exercise effective control over Turnip (Brassica campestris) and Wild Basil (Galinsoga parvifolia). Metribuzin is the herbicide more commonly used. It shows excellent control over the majority of the broadleaf weeds, but phytotoxicity has been observed in certain cultivars, such as Shepody and Innovator [16] [17]. Besides, several authors have cited weed resistance to this herbicide in areas where it was used in excess [18] [19]. Another widely used herbicide is Bentazon, which is applied as a complement of Metribuzin, since control different weeds. For example Spiny cocklebur, Annual vine and Sunflower are controlled by Bentazon and not by Metribuzin, while Knotweed is effectively controlled by Metribuzin, but not by Bentazon. However, Bentazon also showed some phytotoxic effects, depending on the variety [19] [20]. Then, within this framework, any new development is desirable, as will increase the options to properly managed weeds affecting the crop, especially if the new herbicides have a broader weed control spectrum. Recently, Clomazone (Command $36 \mathrm{CS}^{\oplus}$; 2-[(2-chlorophenyl) methyl]-4, 4-dimethyl-3-isoxazolidinone), an herbicide already used in potato crops in other countries has been registered to be used in potato cultivation, in Argentina. Then, the objective of this work was to assess its performance, regarding weed control, crop yield and quality. Since the time this experiment was performed until 2016, the only new herbicide registered in Argentina for potatoes was Rimsulfuron (Titus ${ }^{\circledast}$ by Dupont ${ }^{\circ}$ CASAFE [15]).

\section{Materials and Methods}

The field work was carried out at Balcarce, province of Buenos Aires $\left(37^{\circ} 49^{\prime} 9.65^{\prime \prime} \mathrm{SL}\right.$ $58^{\circ} 13^{\prime} 11^{\prime \prime} \mathrm{WL}$ ), during the spring-summer season 2008/09, in a commercial crop of the variety Innovator. Fertilization was based on soil analysis, which shown medium levels of organic matter (OM\%), sulphur (S), and phosphorus (P) and low levels of nitrogen $(\mathrm{N})$, as shown in Table 1.

\subsection{Soil and Crop Management}

Soil preparation was carried out as normally done in the area: A disk harrow (2 times)

Table 1. Soil characteristics at the experimental site, Balcarce 2008/2009.

\begin{tabular}{cccccc}
\hline Depth $(\mathrm{cm})$ & $\mathrm{OM}(\%)$ & $\mathrm{pH}$ & $\mathrm{P}(\mathrm{ppm})$ & ${\mathrm{N}-N 0_{3}(\mathrm{ppm})}$ & ${\mathrm{S}-\mathrm{SO}_{4}(\mathrm{ppm})}^{2}$ \\
\hline $00-20$ & 4.9 & 6.1 & 15.2 & 10.3 & 7.3 \\
$20-40$ & --- & --- & 7.1 & 6.7 & 7.0 \\
\hline
\end{tabular}


and a chisel plough with a tooth harrow (3 times). Before planting $3 \mathrm{l} \cdot \mathrm{ha}^{-1}$ Metalochlor (Dual Gold ${ }^{\oplus}$, Syngenta) was applied and incorporated with the last chisel plough to control Yellow Nutsedge (Cyperus esculentus), as normally done in this region. Planting was carried out on $22^{\text {nd }}$ November 2008, with a four row planter, at $0.85 \mathrm{~m}$ between rows and 5 seed pieces per lineal meter. Seed was cut $\left(50 \mathrm{~g} \cdot \mathrm{cut}^{-1}\right)$ and treated with Vi$\operatorname{tavax}^{\oplus}\left(600 \mathrm{cc} \cdot \mathrm{t}^{-1}\right)$. Fertilization was performed with $170 \mathrm{~kg} \cdot \mathrm{ha}^{-1}$ diammonium phosphate (18-46-0) and $130 \mathrm{~kg} \cdot \mathrm{ha}^{-1}$ Urea (46-0-0) applied in pre-planting; $468 \mathrm{~kg} \cdot \mathrm{ha}^{-1} \mathrm{di}-$ ammonium phosphate applied at planting, and $60 \mathrm{~kg} \cdot \mathrm{ha}^{-1}$ of Urea applied during crop growth. Crop emergence, which was considered when $>80 \%$ of the plants were above soil level, occurred on $12^{\text {th }}$ December 2008. Management of pests and diseases was carried out according to the variety profile for the region [21].

\subsection{Herbicide Treatments}

Herbicide treatments were applied by using a completely randomized design with three replications, in plots of 6 rows $\times 15 \mathrm{~m}$ long $\left(76.5 \mathrm{~m}^{2}\right)$. Treatments and rates applied are described in Table 2.

\subsection{Weed Population and Weed Control Assessment}

To assess weed population density (plants $\mathrm{m}^{-2}$ ) in each treatment, at 45 days after planting (DAP) five counts per replication were made; each count covering and area of $1 \mathrm{~m}^{2}$.

To determine which herbicide or herbicide combination produce better results, the effectiveness of each treatment was assessed (Treatment Effectiveness, TE). TE was determined by visual observations of each replication and treatment, using a scale ranging from (1) without herbicide symptoms in the weeds-as in the control treatment-, to (10) for total death of the weed plants, as described by Eyherabide [22]. Visual observations were carried out on $30^{\text {th }}$ December 2008; $14^{\text {th }}$ January and $2^{\text {nd }}$ February 2009, at 38,53 and 72 DAP.

To determine how the crop competed with weeds, a crop competition level was established (CCL) by means of visual observations with a scale ranging from (1), for very low competition, to (10), for very high competition. The assessment was made on $14^{\text {th }}$ April 2009, at 143 DAP.

Table 2. Description of the herbicides treatments, Balcarce 2008/2009.

\begin{tabular}{llc}
\hline \multicolumn{1}{c}{ Treatment } & \multicolumn{1}{c}{ Active Ingredient } & Rate $\left(1 \cdot \mathrm{ha}^{-1}\right)$ \\
\hline 1. Untreated control -without weed suppression- & -- & -- \\
2. Clomazone 1.6 & Clomazone ${ }^{(*)}$ & 1.6 \\
3. Clomazone 2.0 & Clomazone & 2.0 \\
4. Clomazone 1.0 + Metribuzin 0.75 & Clomazone + Metribuzin & $1.0+0.75$ \\
5. Clomazone $1.6+$ Metribuzin 0.50 & Clomazone + Metribuzin & $1.6+0.5$ \\
6. Metribuzin 1.35 & Metribuzin & 1.35 \\
\hline
\end{tabular}

Ref: ${ }^{(*)}$ Command 36 CS $^{\star}$ FMC Argentina; ${ }^{(*)}$ Sencorex ${ }^{\star} 48$, BayerCropscience. 
Finally, a weed suppression index (WSI) was established, ranging from (1) poor to (100) excellent, according to the following formula:

$$
\mathrm{WSI}=\mathrm{TE}{ }^{\star} \mathrm{CCL}
$$

\subsection{Tuber Yield and Quality}

On $14^{\text {th }}$ April 2009, at 143 DAP, three fractions of 3 lineal m per replication, from the two central rows of each plot were harvested. From these fractions total tuber weight was assessed, as well as the percentage distribution and weight of tubers in the $<50$ $\mathrm{mm} ;>50 \mathrm{~mm} ;>75 \mathrm{~mm}$ and $>90 \mathrm{~mm}$ fractions, in length.

Dry matter percentage (DM\%) of the tubers, was derived from the specific gravity (SG), that was assessed according to the weight in air/weight in water method, as follows:

$$
\mathrm{SG}=a /(a-b)
$$

where $a=$ weight of the sample in air, and $b=$ weight of the sample immersed in water, then:

$$
\mathrm{DM} \%=24.180+211.04 *(\mathrm{SG}-1.0988)
$$

The frying color was assessed by frying 10 strips, randomly selected from 10 tubers per replication, and by comparing that color with the USDA color chart. From these results a Fry Color Index ranging from (0) for light yellow to (100) for dark brown was calculated, as follows:

$$
\mathrm{FCI}=[[(\# 00 * 1)+(\# 0 \star 2)+(\# 1 * 3)+(\# 2 * 4)+(\# 3 * 5)+(\# 4 * 6)]-10] * 2
$$

The level of defects was also analyzed as normally done at the McCain Raw Material Receiving Lab and results are expressed as level of defects (in\%). Results were statistically analyzed through an ANOVA using the program Sigma Stat ${ }^{\oplus}$ at a significance level of 0.1 .

\section{Results and Discussion}

\subsection{Weed Population and Weed Control Assessment}

In general, Clomazone showed an excellent performance, even under low soil moisture conditions, and did not loss activity, as it is the case with other compounds. Besides, absorption of Clomazone is through the apical bud of the weed, which means that it does not require direct contact with the roots to ensure an effective control [23]. At 45 DAP the following weeds were observed in the trial plots: Spiny Cocklebur, Common Lambsquarter, Purslane, Hairy Crabgrass (Digitaria sanguinalis), and Knotweed. This initial survey showed that weed density can be considered as an intermediate situation when compared with other fields in the Argentinian Pampas (Table 3).

As a general rule, low levels of TE were associated with low CCL at harvest time. When Clomazone 1.6 was applied, TE was higher than for the control treatment, but lower than Clomazone 2.0 and Clomazone $1+$ Metribuzin 0.75, which achieved the higher TE. Besides, the increase in TE when the Clomazone rate was increased from 1.6 
to 2.0, when applied alone, showed the benefits of increasing the rate. When the combination Clomazone 1.6 + Metribuzin 0.5 was applied the TE decrease compared with the Clomazone $1.0+$ Metribuzin 0.75 . This shows that it is the right combination of herbicides and rates which improves TE. The synergy of Clomazone $1.0+$ Metribuzin 0.75, was evident, as this combination showed the highest TE, CCL and WSI; and the treated plots remain weed-free until harvest. Moreover, this is the right combination of herbicides when Common Lambsquarter is present, as already demonstrated by Lanfranconi et al. [24]. The most common herbicide application carried out by growers in the Argentinian pampas is Metribuzin 1.35, applied alone: Results regarding TE, support the previous idea, as with this application TE, CCL and WSI decreased, significantly, when compared with the Clomazone + Metribuzin combinations (Table 4).

At harvest (143 DDP), Common Lambsquarter plants of up to $1.8 \mathrm{~m}$ height were observed in the control treatment, linked to a very low CCL and associated, also, with a very low WSI. When weeds emerge together with the crop and are not controlled, crop competition ability is very low, as already found by Nelson and Thoreson [14], who determined reductions in yields of $54 \%$ when weeds emerged together with the crop and reductions of $16 \%$ when they emerged 3 weeks later; allowing the crop to better compete with them. When Clomazone 1.6 was applied, there was not an adequate control of Common Lambsquarter and Spiny Cocklebur, then CCL and WSI were low, when compared with the Clomazone 2.0 or the Clomazone + Metribuzin combinations (Table 4).

Table 3. Initial weed density at the experimental site, Balcarce 2008/2009.

\begin{tabular}{lccccc}
\hline & $\begin{array}{c}\text { Spiny } \\
\text { Cocklebur }\end{array}$ & $\begin{array}{c}\text { C. } \\
\text { Lambsquater }^{(2)}\end{array}$ & Purslane $^{(3)}$ & $\begin{array}{c}\text { Hairy } \\
\text { Grass }^{(4)}\end{array}$ & Knotweed $^{(5)}$ \\
\hline Weed density $\left(\mathrm{pl} \cdot \mathrm{m}^{-2}\right)$ & 0.6 & 1.6 & 0.6 & 0.4 & 0.4 \\
\hline
\end{tabular}

References: ${ }^{1}$ Xanthium spinosum; ${ }^{2}$ Chenopodium album; ${ }^{3}$ Portulaca olearaceae, ${ }^{4}$ Digitaria sanguinalis, ${ }^{5}$ Polygonum aviculare.

Table 4. Treatment effectiveness (TE), crop competition level (CCL) and weed suppression index (WSI), Balcarce 2008/2009.

\begin{tabular}{lccc}
\hline \multicolumn{1}{c}{ Treatments } & $\mathrm{TE}^{(1)}$ & $\mathrm{CCL}^{(2)}$ & $\mathrm{WSI}^{(3)}$ \\
\hline Untreated control -without weed suppression- & $1.00 \mathrm{~d}$ & $1.30 \mathrm{c}$ & $1.30 \mathrm{f}$ \\
Clomazone 1.6 & $3.50 \mathrm{~b}$ & $2.70 \mathrm{c}$ & $9.45 \mathrm{e}$ \\
Clomazone 2.0 & $6.50 \mathrm{a}$ & $7.70 \mathrm{ab}$ & $50.05 \mathrm{~b}$ \\
Clomazone 1.0 + Metribuzin 0.75 & $6.50 \mathrm{a}$ & $9.0 \mathrm{a}$ & $58.50 \mathrm{a}$ \\
Clomazone 1.6 + Metribuzin 0.5 & $4.50 \mathrm{bc}$ & $8.0 \mathrm{ab}$ & $36.00 \mathrm{c}$ \\
Metribuzin 1.35 & $3.90 \mathrm{c}$ & $6.70 \mathrm{~b}$ & $26.13 \mathrm{~d}$ \\
\hline
\end{tabular}

References: ${ }^{(1)} \mathrm{TE}$, for Treatment Effectiveness, ranging from (1) without herbicide symptoms in the weeds to (10) total weed death; ${ }^{(2)} \mathrm{CCL}$, for Crop Competition Level, ranging from (1) very low crop competition to (10) very high crop competition; ${ }^{(3)}$ WSI, for Weed Suppression Index $=\mathrm{TE} * \mathrm{CCL}$, ranging from (0) poor suppression to (100) excellent suppression. 


\subsection{Tuber Yield and Quality}

As expected, the untreated control, where weeds were not controlled along the crop cycle, showed the lowest yield. In this field trial, not controlling the weeds, leads to a yield reduction ranging from 6.6 to $21 \mathrm{t} \cdot \mathrm{ha}^{-1}$, when the lowest and highest yielding treatments are compared. These results are consistent with those from Beltrano and Caldiz [9], who estimated decreases in yield of up to $95 \%$ in plots with increasing densities of Johnsongrass from 17 to $50 \mathrm{pl} \cdot \mathrm{m}^{-2}$. Besides, the untreated control also showed a lower DM\%, a high percentage of tubers in the fraction $<50 \mathrm{~mm}$, and a higher level of total defects. Application of Clomazone 1.6 determined a lower WSI and a yield similar to the untreated control. However, when Clomazone was applied at a higher rate (2 l.ha ${ }^{-1}$ ) or combined with Metribuzin (Clomazone $1.0+$ Metribuzin 0.75) a significant yield increased was achieved (Table 5). This was due to the higher level of TE, CCL and WSI that was observed in these two treatments. These results also confirmed those from Caldiz and Panelo [11] who demonstrated that yield reductions in the potato crop are mainly due to the competition of broadleaf weeds, for example Common Lambsquarter, which was not well controlled by Clomazone when applied alone at the lowest rate $\left(1.6 \mathrm{l} \cdot \mathrm{ha}^{-1}\right)$. When Clomazone was applied at a higher rate or combined with $\mathrm{Me}$ tribuzin (Clomazone $1+$ Metribuzin 0.75) TE, CCL and WSI were higher, as well as the total yield (Table 5). In general, the lower the WSI the lower the yield and DM\% and higher the percentage of tubers in the $<50 \mathrm{~mm}$ fraction and the total defects, at the end this combination of low yield and poor quality impact negatively on crop value (data not shown). However, no effects were observed over the FCI of the tubers.

Lanfranconi et al. [25] also showed that the presence of weeds such as Common Lambsquarter and Purslane, in a crop of cv. Kennebec, decreased yield in the range of $11 \%-29 \%$ when the best treatment was compared with the untreated control. In the present work similar results were obtained and yield differences of up to $40 \%$ were achieved when the best treatment was compared with the untreated control. The lower yield reductions obtained in cv. Kennebec could be due to its higher competitive ability, as it has a dense canopy, with thicker stems and larger leaves than Innovator [3]. When the Clomazone + Metribuzin were combined at the rates of 1.6 and $0.51 \cdot \mathrm{ha}^{-1}$, respec-

Table 5. Results of the different treatments upon yield and quality, Balcarce 2008/2009.

\begin{tabular}{lrrrrr}
\hline \multicolumn{1}{c}{ Treatments } & Yield (t.ha $\left.{ }^{-1}\right)$ & DM (\%) & $<50 \mathrm{~mm}(\%)$ & Defects $^{1}(\%)$ & FCI $^{2}$ \\
\hline Untreated control -without weed suppression- & $31.87 \mathrm{~d}$ & $18.07 \mathrm{~d}$ & $11.64 \mathrm{~b}$ & $18.20 \mathrm{~b}$ & $5.33 \mathrm{a}$ \\
Clomazone 1.6 & $38.36 \mathrm{~cd}$ & $19.47 \mathrm{ab}$ & $5.89 \mathrm{a}$ & $12.70 \mathrm{~b}$ & $0.00 \mathrm{a}$ \\
Clomazone 2.0 & $50.58 \mathrm{ab}$ & $18.60 \mathrm{~cd}$ & $9.57 \mathrm{ab}$ & $0.76 \mathrm{a}$ & $0.00 \mathrm{a}$ \\
Clomazone 1.0 + Metribuzin 0.75 & $52.85 \mathrm{a}$ & $20.07 \mathrm{a}$ & $7.61 \mathrm{ab}$ & $10.56 \mathrm{~b}$ & $1.33 \mathrm{a}$ \\
Clomazone 1.6 + Metribuzin 0.5 & $44.03 \mathrm{bc}$ & $19.47 \mathrm{ab}$ & $4.71 \mathrm{a}$ & $0.00 \mathrm{a}$ & $0.00 \mathrm{a}$ \\
Metribuzin 1.35 & $45.30 \mathrm{bc}$ & $19.00 \mathrm{bc}$ & $5.22 \mathrm{a}$ & $14.19 \mathrm{~b}$ & $0.00 \mathrm{a}$ \\
\hline
\end{tabular}

References: ${ }^{1}$ Total defects, in percentage; ${ }^{2} \mathrm{FCI}$ for Fry Color Index, as follows, from (0) for light yellow to (100) for dark brown. 
tively, a lower performance was achieved, regarding TE, CCL, WSI, and consequently yield. Similar results were observed when Metribuzin was applied alone at $1.35 \mathrm{l} \cdot \mathrm{ha}^{-1}$ (Table 4 and Table 5). As already mentioned, it was the suitable combination of herbicides and rates which lead to higher yields, and this is partly explained by the high correlation between TE and tuber yield, and WSI and tuber yield, as shown in Figure 1 and Figure 2.

Weed competition did not only impact negatively on yield; it also has a negative effect, in general, on DM\% and in the level of defects, but correlations between WSI and DM\% and WSI with the level of total defects, were low $\left(r^{2}: 0,187\right.$ and 0.264 , respectively; data not shown). A significantly low DM\% and a high level of defects were achieved by the untreated control. These results could be explained due to the interference of weed

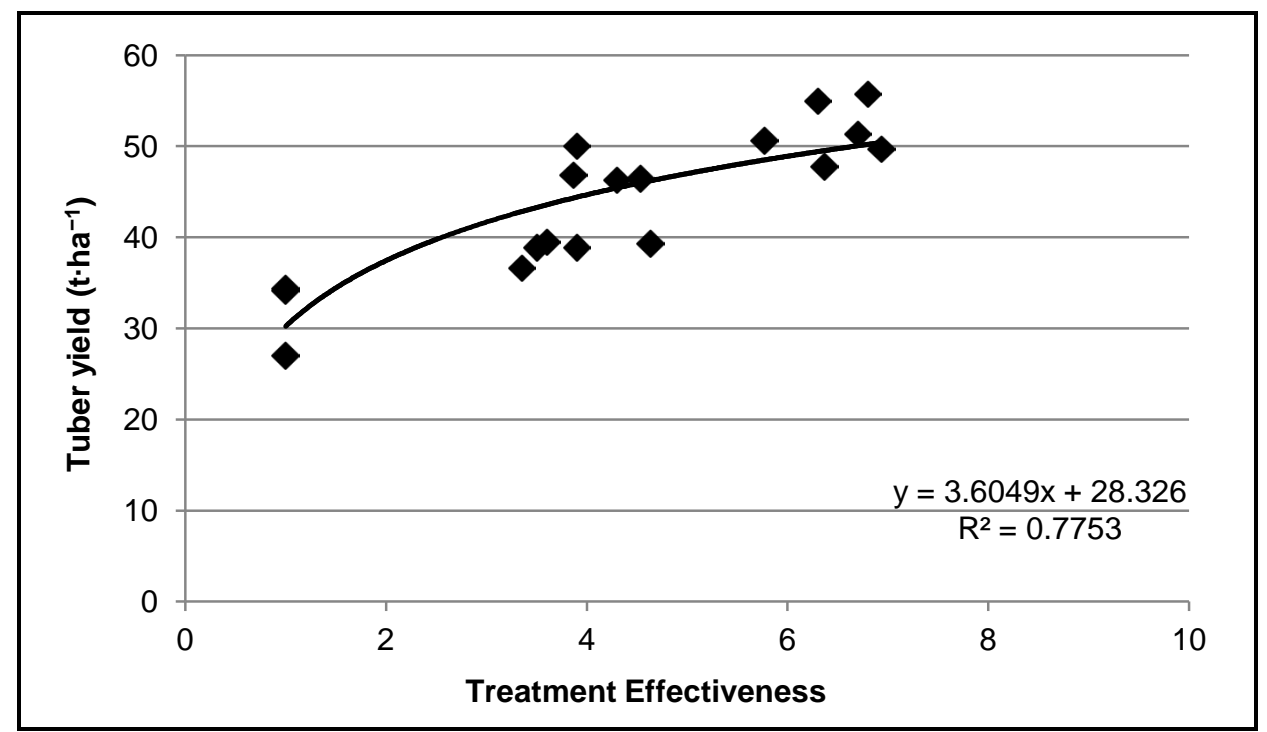

Figure 1. Relationship between Treatment Effectiveness (TE) and tuber yield.

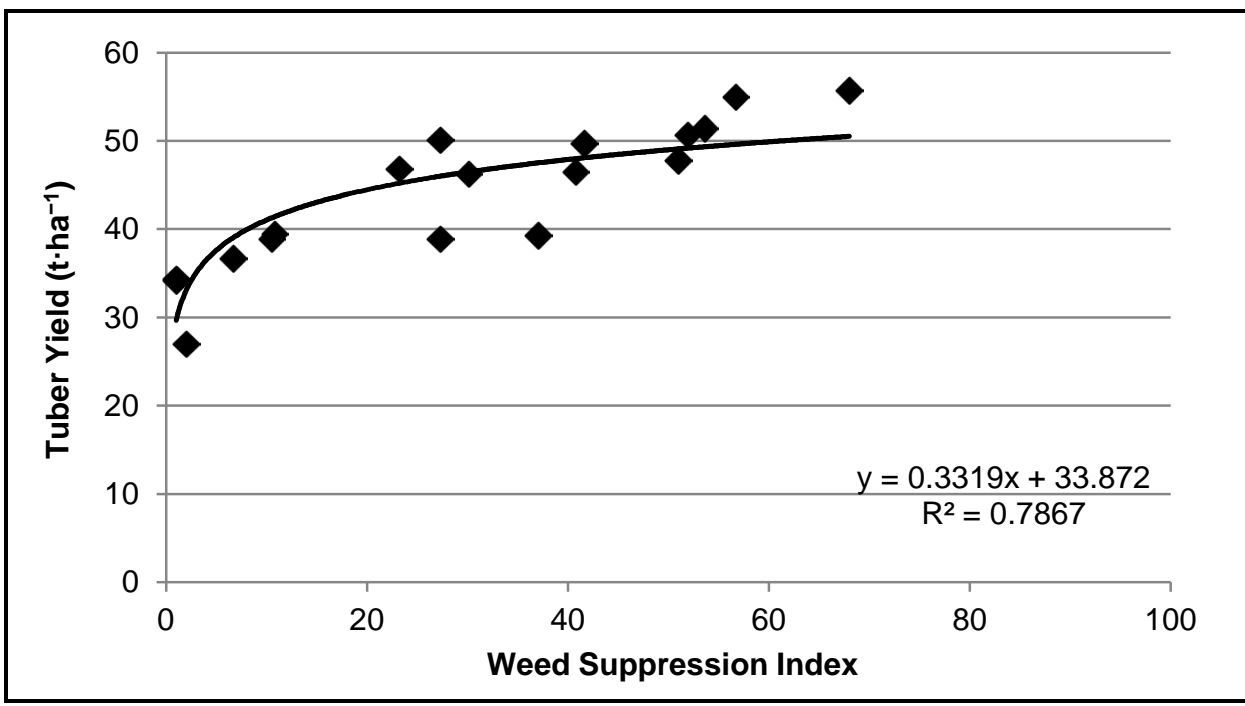

Figure 2. Relationship between Weed Suppression Index (WSI) and tuber yield. 
biomass on radiation interception that could have affected yield and dry matter accumulation, while the effect on total defects could be a consequence of the irregular radiation absorption impacting on tuber growth (malformations).

\section{Conclusion}

Hence, it can be concluded that under the environmental conditions of the Argentinian pampas, weed competition could not only impact upon yield but also on tuber quality. Besides, it was also demonstrated that the use of Clomazone, alone or combined with Metribuzin at proper rates, significantly increase yield and DM\%, while improve tuber quality in terms of size and level of defects. Definitively, in the potato crop, weeds should be properly managed to guarantee achieving high yield and quality.

\section{Acknowledgements}

Support from the staff at the McCain Quality Assurance Raw Material Laboratory at Balcarce is gratefully acknowledged.

This paper is based on the Graduate Thesis of Pablo Bisio, "Control de malezas gramíneas y latifoliadas en papa (Solanum tuberosum L.) con el herbicida Clomazone en el sudeste Bonaerense", Facultad de Ciencias Agrarias, Universidad Nacional de Mar del Plata, November 2014.

\section{References}

[1] Anderson, P.K. (2008) Nueva luz sobre un tesoro enterrado. http://www.fao.org/potato-2008

[2] FAO (2008) Food and Agriculture Organization of the United Nations. Quote in: Nueva luz sobre un tesoro enterrado. http://www.potato2008.org

[3] Caldiz, D.O. (2007) Producción, Cosecha y Almacenamiento de Papa en la Argentina. 2nd Edition, McCain Argentina SA, Balcarce - BASF Argentina SA, Ciudad Autónoma de Buenos Aires, Argentina.

[4] Napolitano, G.H. (2012) Estudio del Sistema de Agronegocios de la papa en la Argentina. Mi-nisterio de Agricultura, Ganadería y Pesca, SAGPyA, PROSAP, IICA. Buenos Aires, Argentina, 173.

[5] Mendiburu, A.O. and Lucarini, O. (1980) Manipulaciones genéticas para la producción y el aprovechamiento de la papa. Revista de la Facultad de Agronomía Buenos Aires, 1, 129139.

[6] Escarrá, A.M. (1989) Etapa de consolidación del abastecimiento. Hacia la exportación de se-milla? Enfoques del Sudeste, 51, 9-13.

[7] Eyherabide, J.J. (1995) Problemática del control de malezas en papa. EEA Balcarce - Facultad de Ciencias Agrarias, UNMDP, Balcarce, Argentina.

[8] de Lasa, C. and Caldiz, D.O. (2009) Weed Management. In: McCain South America Agronomy Report 2009, McCain Argentina S.A. Internal Report.

[9] Beltrano, J. and Caldiz, D.O. (1993) Effect of Johnsongrass (Sorghum halepense L. Per) on potato (Solanum tuberosum L.) Yield. Pesquisa Agropecuaria Brasileira, 28, 21-24.

[10] Butzonich, I.P., Montes, I., Induni, S. and Alonso S.I. (1984) Solanum sisymbriifolium Lam; reservorio de virus Y de la papa en el sudeste de la provincia de Buenos Aires. Fitopatología, 
19, 89-92.

[11] Caldiz, D.O. and Panelo, D.M. (1986) Efectos de la competencia de malezas de hoja ancha y angosta sobre el crecimiento y el rendimiento en papa. Revista Facultad de Agronomía La Plata, 62, 37-43.

[12] Hutchinson, P.J.S. (2014) Hairy Nightshade: Critical Interference Period in Potatoes. Weed Technology, 28, 543-551. http://dx.doi.org/10.1614/WT-D-13-00160.1

[13] Van Gessel, M.J. and Renner, K.A. (1990) Redroot Pigweed (Amarantus retroflexus) and Barnygrass (Echinochloa crus-galli) Interference in Potatoes (Solanum tuberosum L.). Weed Science, 38, 338-343.

[14] Nelson, D. and Thoreson, M. (1981) Competition between Potatoes and Weeds. Weed Science, 9, 672-677.

[15] CASAFE (2013) Guía de productos fitosanitarios para la República Argentina. 16th Edition. Buenos Aires, Argentina.

[16] Caldiz, D.O. (2002) Características de las variedades de papa utilizadas por la industria. Del Campo a la Fábrica, 2, 1-4.

[17] Alberta Agriculture (1993) Crop protection with Chemicals. Alberta Agriculture, Edmonton, AB, Agdex 606, 131-158.

[18] Callihan, R.H., Ojala, J.C., Haderline, L.C. and Kidder, D.W. (1990) Nightshade Biology and Control in Cropland of the Pacific Northwest. Pacific Northwest Cooperative Extension Bulletin No 352.

[19] Eberlein, C.V., Guttieri, M.J. and Schaffers, W.C. (1992) Hairy Nightshade (Solanum sarrachoides) Control in Potatoes (Solanum tuberosum L.) with Bentazon and Additives. Weed Technology, 6, 85-90.

[20] Love, S.L. and Haderlie, L.C. (1991) Potato (Solanum tuberosum) Cultivar Response to Bentazon and Crop Oil. American Potato Journal, 68, 331-342. http://dx.doi.org/10.1007/BF02853670

[21] Caldiz, D.O. (2004) Características y manejo de la variedad Innovator. Del Campo a la Fábrica, 4, 2-5.

[22] Eyherabide, J.J. (2001) Aplicación de Metribuzín a seis cultivares de papa en dos momentos de crecimiento del cultivo. Cátedra de Terapéutica vegetal, FCA, UNMDP, Balcarce, Argentina.

[23] CASAFE (2009) Guía de productos fitosanitarios para la República Argentina. 4th Edition, Buenos Aires, Argentina.

[24] Lanfranconi, L., Remondino, L. and Oliva, J. (2012) Seis años de evaluación de herbicidas pre emergentes en el cultivo de papa en la provincia de Córdoba. INTA Manfredi Boletín Número 30.

[25] Lanfranconi, L., Toraglio, E. and Caldiz, D.O. (2006) Suceptibilidad varietal y eficiência de uso de metribuzin em papa (Solanum tuberosum). Informe Interno INTA Río Primero, Córdoba, Argentina. 
Submit or recommend next manuscript to SCIRP and we will provide best service for you:

Accepting pre-submission inquiries through Email, Facebook, LinkedIn, Twitter, etc. A wide selection of journals (inclusive of 9 subjects, more than 200 journals)

Providing 24-hour high-quality service

User-friendly online submission system

Fair and swift peer-review system

Efficient typesetting and proofreading procedure

Display of the result of downloads and visits, as well as the number of cited articles

Maximum dissemination of your research work

Submit your manuscript at: http://papersubmission.scirp.org/

Or contact ajps@scirp.org 